\title{
Factors Inhibiting the Dietary Compliance of the Patients with Diabetes Mellitus
}

\author{
Atyanti Isworo", Khairun Nisa Latifah and Arif Setyo Upoyo \\ Nursing Department, Faculty of Health Sciences, Jenderal Soedirman University, Indonesia \\ Jalan Dr.Gumbreg, Medical Street, Kota Purwokerto, Jawa Tengah 53146 \\ *Corresponding author: atyanti.isworo@gmail.com
}

\begin{abstract}
Background: The blood glucose level of patients with Diabetes Mellitus is influenced by their dietary compliance. The dietary compliance of patients with Diabetes Mellitus is influenced by various inhibiting factors, including income, environment, and information from the health professionals. Objective: The purpose of the research is to figure out the factors inhibiting the dietary compliance of patients with Diabetes Mellitus at Purwokerto Utara Public Health Center. Method: This research uses a correlation analytical design with a cross sectional approach. 87 samples are collected using a simple random sampling method. The research instruments are questionnaires of Barriers to Diet Self Care Scale as well as those for income, environment, and information from the health professionals. Result: A bivariate analysis is conducted using Spearman correlation test. The research results show there is no significant relationship between income and the dietary compliance barriers $(p=0.145)$. However, there is a significant relationship between environment and the dietary compliance barriers ( $p=0.000$; $r=0.534)$ as well as between information from the health professionals and the dietary compliance barriers ( $p=0.000 ; r=0.427$ ). Conclusion: The higher the inhibition of environment and information from the health professionals, the higher the dietary compliance barriers of patients with Diabetes Mellitus.
\end{abstract}

Keywords:

Diabetes Mellitus, income, environment, information from the health professionals; and dietary compliance barriers.

\section{INTRODUCTION}

Diabetes Mellitus (DM) is a chronic disease which prevalence rapidly increases. The Indonesia Diabetes Mellitus prevalence in 2000 as predicted by the World Health Organization (WHO) has reached 8.4 million people and may increase more to approximately 21.3 million people in 2030 (Indonesian Endocrinology Association (Perkeni, 2011). This condition leads Indonesia to the fourth highest rank on Diabetes Mellitus prevalence after China, India and the United States (WHO, 2013).

There are many patients with Diabetes Mellitus chronic complication due to the poor implementation of dietary management (Betteng, Pangemanan, \& Mayulu, 2014). Diet is the most important part in Diabetes Mellitus management that the blood glucose level may be stabilized. The low dietary compliance of the patients with Diabetes Mellitus is due to some inhibiting factors (Lestari, 2012). The factors influencing the patients with Diabetes Mellitus not to comply the diet include income, environment, and information from the health professionals.

Income is considered inhibiting the recommended behaviors (Fitzpatrick, et al, 2004). The patients' low income may inhibit the treatment processes recommended by health care workers (Onwudiwe, et al, 2011). It is assumed that income is inversely 
proportional to the healthy lifestyle. The higher the income, the lower the percentage of people with healthy diet is. Higher income facilitates people to obtain food easier through the delivery order system.

The environment is also considered inhibiting the health promotion (McCabe, 2003). The environment covers residence, family, and working place. The supporting environment may encourage an individual to have healthy lifestyle and by more obedient to the health treatments (Weston, 2008).

Health professionals have an important role to improve the quality of health services. In facts, however, the health professionals' services are not maximally provided that the information should be delivered is limited. Limited information may inhibit the patients with Diabetes Mellitus self-management (Brown, et al, 2004). The information given by the doctor is considered inadequate due to the short consultation time. Thus, some information is considered confusing. However, some similar studies find that the information given by the doctor is excellent and useful to control the patients' glucose level properly.

\section{METHOD}

This research uses a correlation analytical design with a cross sectional approach. The samples are collected using a simple random sampling technique with inclusion criteria covering those who are willing to be the respondents, living together with the family, and long enough suffering from Diabetes Mellitus ( $\geq 1$ year). The research instruments are questionnaires consisting of sheets on respondents' characteristics (age, gender, education level, and occupation), income, environment, information from the health professionals, and diet compliance barriers. Spearman Rank is employed to analyze the inhibiting factors related to the dietary compliance of patients with Diabetes Mellitus.

\section{RESULT AND DISCUSSION}

In this research, the respondents' characteristics are based on age, sex, education level and occupation.

Table 1 Distribution of respondents' characteristics

\begin{tabular}{lll}
\hline Characteristics & $\begin{array}{l}\text { Frequency } \\
\text { Median }\end{array}$ & $\begin{array}{l}\text { Percentage } \\
\text { Minimum-Maximum }\end{array}$ \\
\hline $\begin{array}{l}\text { Age } \\
\text { < 45 years old }\end{array}$ & 3 & $3.4 \%$ \\
$45-59$ years old & 32 & $36.8 \%$ \\
$>59$ years old & 52 & $59.8 \%$ \\
Sex & & \\
Male & 35 & $40.2 \%$ \\
Female & 52 & $59.8 \%$ \\
Education Level & & \\
Having No Formal Education & 2 & $2.3 \%$ \\
Elementary School & 34 & $39.1 \%$ \\
Junior High School & 17 & $19.5 \%$ \\
Senior High School & 22 & $25.3 \%$ \\
University & 12 & $13.8 \%$ \\
Occupation & & \\
Working & 21 & $24.1 \%$ \\
Not/No Longer Working & 66 & $75.9 \%$ \\
Income & 2 million & 400 thousand-6 million \\
Environment & 8 & $1-12$ \\
Information from health professionals & 30 & $18-45$ \\
Dietary compliance barriers & 26 & $12-37$ \\
\hline
\end{tabular}


Table 1 above shows that most respondents are at the age of more than 5 years $(59.8 \%)$ and female $(59.8 \%)$. The respondents' most education level is elementary school $(39.1 \%)$. Most respondents are not working/no longer working $(75.9 \%)$ and their average income is 2 million rupiahs per month. The average environmental barriers are 8 (1-12), while the health information barriers are 30 (18-45).

Table 2 The Relationship of Income, Environment and Information from health professionals with the dietary compliance barriers of the patients with Diabetes Mellitus

\begin{tabular}{lllll}
\hline Variable & Median & Min-Max & R & $\boldsymbol{p}$ \\
\hline Income & 2 million & 400 thousand-6 million & -0.157 & 0.145 \\
Environment & 8 & $1-12$ & 0.673 & 0.000 \\
Information from health professionals & 30 & $18-45$ & 0.427 & 0.000 \\
\hline
\end{tabular}

Table 2 above shows that there is no relationship between income and dietary compliance barriers of the patients with Diabetes Mellitus $(p=0.145)$. The obtained research results are in the contrary with those conducted by (McCabe, 2003), stating that the higher the income the higher the dietary compliance barriers are. This is because most respondents are not working $(75.9 \%)$ and female $(59.8 \%)$. It means that the respondents' income is the family's income. The family income may not be entirely spent by the respondents. Moreover to the female patients, they should ask permission to the husband to use the family income. Based on the research conducted by (Onwudiwe, et al, 2011) people who earn their own income may treat themselves better than those who do not have their own income. In this case, the research does not calculate the household needs. Indonesian people tend to think about their health after their needs on food are well fulfilled.

Table 2 above also shows that there is a relationship between environment and the dietary compliance barriers of the patients with Diabetes Mellitus by $p=0,000$ and $r=$ 0.673. It means that the greater the inhibition of environment the greater the dietary compliance barriers of the patients with Diabetes Mellitus. The environment may come from the family, working place, and community. Most respondents state that the family inhibition is due to the food availability. Meanwhile, some respondents state that the working environment and community inhibition are frequently due to the colleagues who invite them to eat any food at any occasions which is inappropriate to their diet, such as arisan (an informal social gathering with small contributions).

Furthermore, there is a relationship between the inhibition of information of health professionals and the dietary compliance barriers of the patients with Diabetes Mellitus. The bigger the inhibition of information from the health professionals the higher the dietary compliance barriers of the patients with Diabetes Mellitus $(\mathrm{p}=0.000 ; \mathrm{r}=0.427)$. The research conducted by Bayliss, Ellis, \& Steiner (2007) who mention that the poor information results in Diabetes Mellitus self-management barriers. Poor information on Diabetes Mellitus is due to the patients with Diabetes Mellitus who tend to have communication difficulties with the health professionals. In brief, the limited consultation time with the health professionals make the patients with Diabetes Mellitus obtain less information related to the disease management.

The research results show that the higher the inhibition of information from the health professionals, the higher the dietary compliance barriers may become. Since the respondents frequently gather with the surrounding people who eat and drink any food provided, they do not comply their diet due to the surrounding situations. The respondents feel no guilty after disobeying their diet which may influence the obtained information as it is only considered as a new knowledge without any application in everyday life.

The research respondents' age which is mostly $>59$ years old may also influence 
the research results. The compliance barriers increase along with the improving age of the patients with Diabetes Mellitus. Most respondents have also low education that they are less active to obtain any information related to their illness.

\section{CONCLUSION}

Environment and information from the health professionals are considered as the inhibiting factors for dietary compliance of the patients with Diabetes Mellitus. The higher the inhibition of both environment and information from the health professionals, the higher the dietary compliance barriers of the patients with Diabetes Mellitus are.

\section{ACKNOWLEDGEMENT}

This research was supported by Institute for Research and Community Services Jenderal Soedirman University. The authors thanks Nia, Putri Wulan, Putri Diah Ratih and Endah Purwaningsih for their dedicated work in collecting data in this article. We are also immensely grateful to the anonymous reviewer for their comments of this article.

\section{REFERENCES}

Bayliss, E. A., Ellis, J. L., \& Steiner, J. F., (2007). Barriers to self-management and quality of life outcomes in seniors with multimorbidities. Annals of Family Medicine, 5(5), 395-402.

Betteng, R., Pangemanan, D., Mayulu, N., (2014). Analisis faktor resiko penyebab terjadinya diabetes melitus tipe 2 pada wanita usia produktif di Puskesmas Wawonasa. Jurnal e-Biomedik (eBM), 2(2), 404-412.

Brown, A.F., Ettner, J., Piette, M, Weinberger, E., Gregga, Shapiro, M., (2004). Socioeconomic position and health among persons with diabetes mellitus: a conceptual framework and review of the literature. Epidemiologic Rev, 26, 63-77.

Onwudiwe, N.C., Mullins, C.D., Winston, R.A., Shaya, F.T., Pradel, F.G., Laird, A., Saunders, E., (2011). Barriers to self management of diabetes: a qualitative study among low income minority diabetics, Ethnicity \& Disease, 21, 27-32.

Perkeni, (2011). Konsensus pengelolaan dan pencegahan diabetes mellitus tipe 2 di Indonesia. Jakarta: Pengurus Perkumpulan Endokrinologi Indonesia.

Fitzpatrick, A. L., Powe, N. R., Cooper, L. S., Ives, D. G., \& Robbins, J. A., (2004). Barriers to health care access among the elderly and who perceives them. American Journal of Public Health, 94(10), 1788-1794.

Lestari, T. S., (2012). Hubungan psikososial dan penyuluhan gizi dengan kepatuhan diet pasien diabetes melitus tipe 2 rawat jalan di RSUP Fatmawati tahun 2012. (Skripsi), Universitas Indonesia, Depok.

McCabe, B. A., (2003). Barriers to adherence in a free medication program for low income individuals with type 2 diabetes. (Dissertation), Louisiana State University.

Weston, N.M., (2008). Identifying perceptions of health promotion barriers and benefits in individuals at riks for coronary heart disease, Montana State University, Montana.

WHO, (2013). Diabetes. Retrivied Januari, 202017 from who.int:http://who.int/media centre/fact sheet/fs312/en/. 